Bangladesh J. Bot. 48(3): 595-601, 2019 (September)

\title{
BACTERIOLOGICAL STUDY OF SOME COMMON DRIED SPICES AND NUTS OF BANGLADESH
}

\author{
Nazia Afrin*, Shamima Nasrin Jolly and Rasheda Yasmin Shilpi \\ Department of Botany, Jahangirnagar University, Savar, Dhaka, Bangladesh \\ Keywords: Spices, Nuts, Identification, Bacteria, Food borne illness
}

\begin{abstract}
The cultivation of spices and nuts in different parts of the world characterized by high humidity and warm climate provides optimum conditions for the development of microorganisms, including the undesirable ones. To identify the microbial risk factor associated with dried spices and nuts samples available in local markets of Bangladesh, samples were collected and analyzed through standard microbiological procedure. In all the spices and nuts samples, the total aerobic heterotrophic bacterial (TAHB) level was below the standard unacceptable range $\left(>10^{6} \mathrm{CFU} / \mathrm{g}\right)$. Both Gram positive and Gram negative pathogenic bacteria viz., Staphylococcus aureus, S. epidermidis, Bacillus sp. and Enterobacter sp. were isolated from samples through screening staining properties, genus and group specific characters on selective and differential media along with morphological and biochemical tests. It could be assumed that dried spices and nuts might be the carrier of these types of pathogenic bacteria in foods when cooked using these ingredients and causes food borne illness.
\end{abstract}

\section{Introduction}

Food poisoning is a common and sometimes life-threatening problem for millions of people all over the world. Foodborne illness resulting from eating food contaminated with bacteria or their toxins are most common and usually caused by bacteria such as Campylobacter, Salmonella, Shigella, E. coli, Listeria and Clostridium botulinum (Ahmed et al. 2014).

All over the world spices are virtually indispensable in the culinary art and used for flavor, color, aroma, taste and preservation of food and beverages. The spices are produced from roots, barks, leaves, bulbs, stems, flowers and seeds of certain plants and mostly grown and harvested in warm, humid areas of the world (Aguilera et al. 2005). On the other hand, worldwide, nuts are esteemed and highly priced food delicacy because of their pleasant taste and flavor in addition to their content of proteins and antioxidants (Alhussaini 2012). Different kinds of edible nuts including almonds, peanuts, hazelnuts, pistachios, walnuts and cashew nuts in addition to many dried fruits are frequently imported in Bangladesh for consumption. Although nuts and spices have continued to be popular food commodities, possible contamination with certain pathogenic microorganisms is a major safety and quality concern for both the industry and consumers. The spices may get contaminated by unwanted microorganisms during their growth and development or when these are passed through collection, processing, storage and marketing (Khan 2012). The traditional methods of harvesting and preparations of these products result in contamination. Finally, at consumers' level these are obviously found with multitude of organisms (Das 2002).

Many workers reported alarming microbiological quality of spices from different parts of the world (Antai 1988, Satchell et al.1989, Koch et al. 2005, Moreira et al. 2009) and instances of recalls of nut and spice products in USA and Canada (CDC 2009). The high microbial loads in spices and nuts prompted an upsurge in monitoring and research related to these food commodities

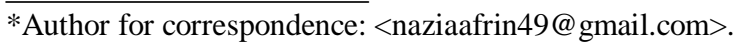


to maintain the quality of nuts and spices all over the world. However, Indian subcontinent, especially in Bangladesh very little attention has been given on this matter. Therefore, the present study was conducted to investigate the microbial loads and identify the pathogenic bacteria associated with microbial contamination of spices and nuts available in the commercial market of Bangladesh.

\section{Materials and Methods}

Six different spices and three nuts were collected from different local markets of Dhaka city. Samples were collected in sterilized plastic bags, closed the opening, brought into the laboratory immediately and preserved for detailed study. The entire experiment was carried out in the laboratory of Microbiology of Botany department, Jahangirnagar University.

Bacterial enumeration and isolation were carried out by spread plate method in nutrient agar medium (NA) (Eklund and Lankford 1967) at $\mathrm{pH}$ 6.0. One gram of sample was suspended in 100 $\mathrm{ml}$ of sterile water in a conical flask and vortexed vigorously for five min. The plates were inoculated with ten-folds diluted suspension and incubated at $37^{\circ} \mathrm{C}$ for $24 \mathrm{hrs}$ in an incubator (Memmert $\mathrm{GmbH}+\mathrm{Co} \mathrm{Kg} 8540$ Sehwabach) at the inverted condition. After incubation, plates having well discrete colonies were selected for counting. Discrete bacterial colonies were isolated immediately after counting. Based on distinct colony morphology, further selection was made and isolates were purified by repeated streaking and stored in NA slants at $4{ }^{\circ} \mathrm{C}$ for further analysis.

The selected bacterial colonies were observed to study various characters viz., color, form, elevation, margin, surface, optical characters (Eklund and Lankford 1967). Bacterial colonies were isolated and cultured on different selective and differential media such as: MSA, SSA, EMB, MacConkey, Bouillon agar, King's B, XLD, Simmon Citrate etc. Presence of Staphylococcus aureus and S. epidermidis was confirmed by the appearance of yellow and pink colonies on MSA media respectively. Presence of Bacillus sp. was confirmed by growth of white colonies on Bouillon agar media while the presence of Enterobacter was confirmed by the appearance of pink colonies on EMB medium. Different major biochemical tests viz., casein, fermentation, indole, starch hydrolysis, catalase were also performed. Results of the physiological and biochemical tests of selected isolates were analyzed following Bergey's Manual of Systematic Bacteriology (Sneath et al. 1986). Coagulase test and endospore staining were used as a confirmation test of bacterial genus or species of Staphylococcus aureus and Bacillus sp., respectively.

\section{Results and Discussion}

Six different spices and three nuts were collected from different local markets of Dhaka city (Table 1). Total aerobic heterotrophic bacterial (TAHB) load of the spice and nut samples were found to range from $4 \times 10^{2}$ to $2.1 \times 10^{5} \mathrm{CFU} / \mathrm{g}$ on nutrient agar media (Table 1). In case of spices, maximum heterotrophic bacterial counts were observed in the fennel sample. While, the lowest bacterial counts were found in cinnamon sample. According to guidelines elaborated by the International Commission on Microbiological Specifications for Foods (ICMSF 2005), the total bacterial count in spices below $10^{4} \mathrm{CFU} / \mathrm{g}$ is indicative of their acceptable quality, the count of $10^{4}$ $-10^{6} \mathrm{CFU} / \mathrm{g}$ indicates their permissible quality, whereas bacterial count exceeding $10^{6} \mathrm{CFU} / \mathrm{g}$ is unacceptable. In view of these guidelines, CFU results showed relatively good quality of the analyzed spices (Table 1). In case of spice cinnamon, TAHB did not exceed $10^{4} \mathrm{CFU} / \mathrm{g}$, which is consistent with the available data proving the antimicrobial activity of this spice (Nabavi et al. 2015). However, research around the world presented different scenario where in some cases spices and nut samples were contaminated with different bacterial species which are higher than acceptable limit viz., black cumin seeds in Saudia Arabia (Al-Jassir 1992) (with $7 \times 10^{7}$ CFU/g) 
while in India were in the range from $1 \times 10^{4} \mathrm{CFU} / \mathrm{g}$ to $1 \times 10^{8} \mathrm{CFU} / \mathrm{g}$ (Bhar et al. 1987), all these values were higher than the present observed value for the cumin. Similarly, in black pepper TAHB was also found to be higher than acceptable range in different regions (Banerjee and Sarkar 2003). In addition, in ground cinnamon of Turkey CFU/g was $5.2 \times 10^{3}$ to $1.2 \times 10^{5}$ (Karapinar and Aktug 1988), clove oil in Australia (Pafumi 1986) and India (Sharma et al. 1984) recorded $1 \times$ $10^{2}$ and $8.7 \times 10^{2} \mathrm{CFU} / \mathrm{g}$ respectively, which was lower than the present findings. Furthermore, Stankovic et al. (2006) also demonstrated that about $50 \%$ of their analyzed spice samples were contaminated with bacteria higher than the acceptable limit. These varying degrees of microbial contamination might be due to different factors, viz., natural antibacterial effects of spice (Burt 2004) and handling and processing involved in production (Witkowska et al. 2011).

Table 1. Collected common dried spices and nuts samples and their bacterial load (CFU/g).

\begin{tabular}{|c|c|c|c|c|c|}
\hline $\begin{array}{l}\text { Sample } \\
\text { no. }\end{array}$ & $\begin{array}{l}\text { Bengali } \\
\text { name }\end{array}$ & $\begin{array}{l}\text { English } \\
\text { name }\end{array}$ & Scientific name & Used part & $\mathrm{CFU} / \mathrm{g}$ \\
\hline 1. & Ellachi & $\begin{array}{l}\text { Lesser } \\
\text { cardamom }\end{array}$ & Elettaria cardamomum & Seedpod & $2.61 \times 10^{4}$ \\
\hline 2. & Daruchini & Cinnamon & Cinnamomum zeylanicum & Bark & $6.6 \times 10^{3}$ \\
\hline 3. & Golmorich & Black pepper & Piper nigrum & Drupe & $1.5 \times 10^{4}$ \\
\hline 4. & Kalozira & Black cumin & Nigella sativa & Seed & $6.1 \times 10^{4}$ \\
\hline 5. & Mouri & Fennel & Foeniculum vulgare & Seed & $2.1 \times 10^{5}$ \\
\hline 6. & Long & Clove & Syzygium aromaticum & Flower bud & $1.41 \times 10^{4}$ \\
\hline 7. & Kath badam & Almond & Prunus dulcis & Seed & $2.37 \times 10^{3}$ \\
\hline 8. & China badam & Peanut & Arachis hypogaea & Seed & $4 \times 10^{2}$ \\
\hline 9. & Kaju badam & Cashew nut & Anacardium occidentale & Seed & $1.47 \times 10^{3}$ \\
\hline
\end{tabular}

Identified bacteria of isolated bacterial colonies from spices and nuts samples are shown in Table 2. In the present study the identified bacteria were Staphylococcus aureus (Fig.1B), S. epidermidis (Fig.1B), and Enterobacter sp. through their respective color in specific culture medium. In addition, results of biochemical tests of different isolates revealed that out of 17 isolates 16 were Gram positive and 1 was Gram negative (Fig.1C) and rod shaped. Among the Gram positive isolates 11 were cocci (Fig.1D) and 5 were rod shaped. All the isolates were catalase positive, casein negative, lactose fermentation negative and indole negative (Table 3). Out of 17 isolates only 5 were positive in starch hydrolysis test (Fig.1E) and endospore staining showed the presence of Bacillus sp. Among 11 cocci shaped bacteria 10 were positive for coagulase test (Fig. 1F) which confirmed the presence of Staphylococcus aureus.

Instead of low CFU count in the present examined samples, presence of pathogenic bacteria, Staphylococcus aureus, S. epidermidis, Bacillus sp. and Enterobacter sp. suggested health risk to the consumers (Table 2). The presence of different pathogenic bacteria has been reported by different authors in spice samples also. For example, Escherichia coli, Serratia sp., Klebsiella sp., Bacillus sp., Staphylococcus sp. and Streptococcus sp. were identified from the composite sample of black and red pepper in the United States (Christensen et al. 1967). Salmeron et al. (1989) found four to six times as much pathogenic Staphylococcus in black pepper than white pepper samples in Spain. All of these findings are in agreement to the present study for the presence of Staphylococcus aureus and other Staphylococcus sp. in observed spice samples. Karapinar and 

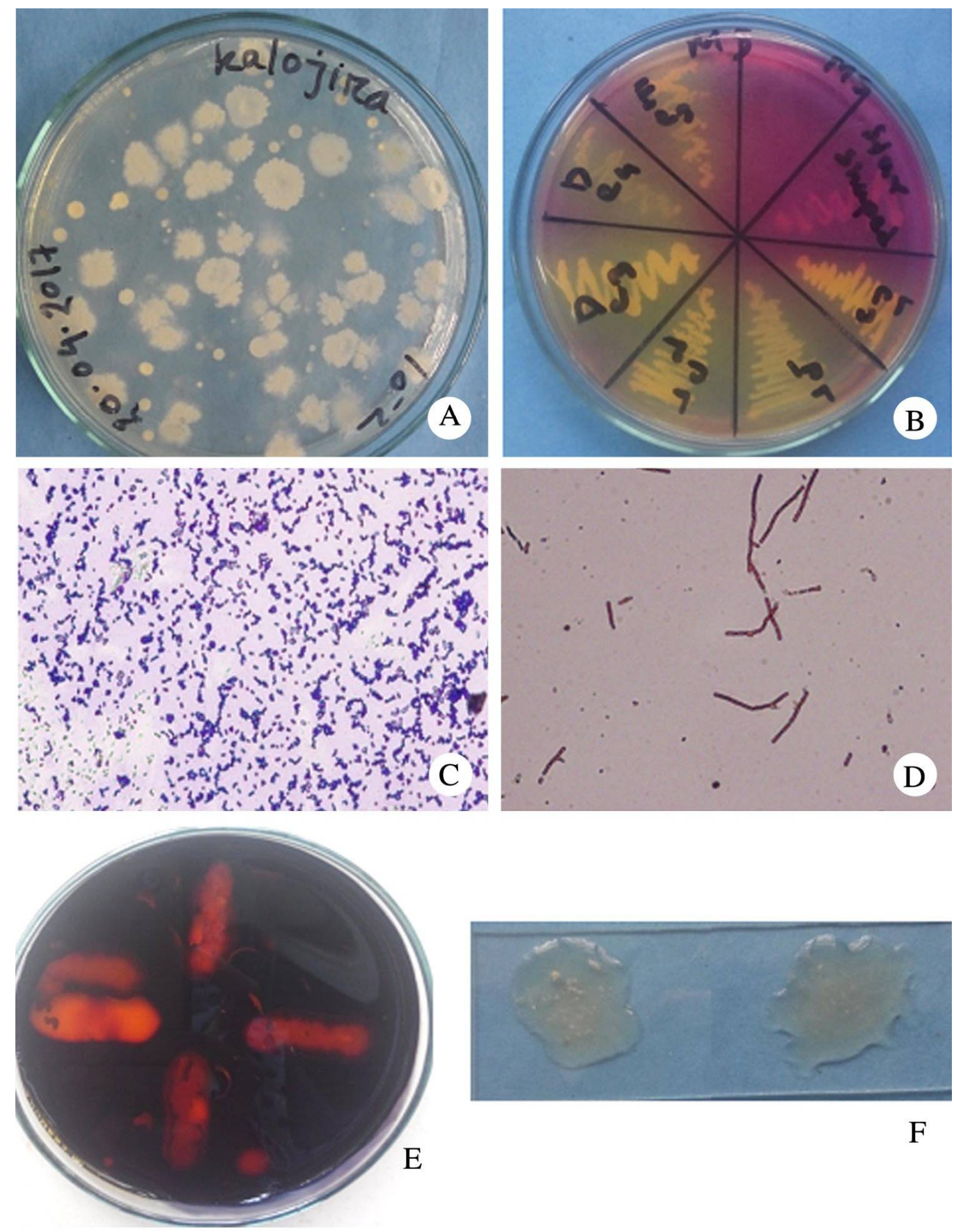

Fig 1. Bacterial isolates on nutrient agar (A), Staphylococcus aureus (yellow colonies) and S. epidermidis (pink colonies) on MSA media (B), Gram staining represents Gram positive (cocci shaped) S. aureus (C) and rod shaped Gram negative Enterobacter (D), starch hydrolysis test (E), coagulase test( + (left) - (right) (F)). 
Table 2. Results of some major biochemical tests of isolated bacterial colonies from spices and nuts samples.

\begin{tabular}{|c|c|c|c|c|c|c|c|c|c|c|}
\hline Sample & $\begin{array}{c}\text { Isolate } \\
\text { No. }\end{array}$ & $\begin{array}{c}\text { Gram } \\
\text { reaction }\end{array}$ & $\begin{array}{l}\text { Cata- } \\
\text { lase }\end{array}$ & Casein & $\begin{array}{c}\text { Fermen- } \\
\text { tation }\end{array}$ & $\begin{array}{c}\text { Starch } \\
\text { hydrol- } \\
\text { ysis }\end{array}$ & Indole & $\begin{array}{l}\text { Coagu- } \\
\text { lase }\end{array}$ & $\begin{array}{l}\text { Endo- } \\
\text { spore }\end{array}$ & $\begin{array}{l}\text { Identified } \\
\text { Bacteria }\end{array}$ \\
\hline $\begin{array}{l}\text { Clove, } \\
\text { Cinnamon, } \\
\text { Lesser } \\
\text { Cardamom }\end{array}$ & LDEC1 & + & + & - & - & + & - & - & + & Bacillus sp. \\
\hline Clove & $\mathrm{LC} 2$ & + & + & - & - & - & - & + & - & $\begin{array}{l}\text { Staphylococcus } \\
\text { aureus }\end{array}$ \\
\hline \multirow{3}{*}{ Cinnamon } & LC3 & + & + & - & - & - & - & + & - & S. aureus \\
\hline & DC4 & + & + & - & - & - & - & + & - & S. aureus \\
\hline & DC5 & + & + & - & - & - & - & + & - & S. aureus \\
\hline $\begin{array}{l}\text { Lesser } \\
\text { Cardamom }\end{array}$ & EC6 & + & + & - & - & - & - & + & - & S. aureus \\
\hline Fennel & $\mathrm{KC} 1$ & - & + & - & - & - & - & _ & - & Enterobacter sp. \\
\hline \multirow{3}{*}{ Black cumin } & $\mathrm{KC} 2$ & + & + & - & - & - & - & + & - & S. aureus \\
\hline & $\mathrm{KC} 3$ & + & + & - & - & - & - & + & - & S. aureus \\
\hline & $\mathrm{KC} 4$ & + & + & - & - & - & - & - & - & S. epidermidis \\
\hline \multirow{3}{*}{$\begin{array}{l}\text { Black } \\
\text { pepper }\end{array}$} & KC5 & + & + & - & - & - & - & + & - & S. aureus \\
\hline & KC6 & + & + & - & - & - & - & + & - & S. aureus \\
\hline & $\mathrm{KC} 7$ & + & + & - & - & - & - & + & _ & S. aureus \\
\hline \multirow[t]{2}{*}{ Cashewnut } & $\mathrm{NC} 1$ & + & + & - & - & - & - & - & + & Bacillus sp. \\
\hline & $\mathrm{NC} 2$ & + & + & - & - & - & - & - & + & Bacillus sp. \\
\hline Almond & NC3 & + & + & - & - & - & - & - & + & Bacillus sp. \\
\hline Peanut & $\mathrm{NC} 4$ & + & + & - & - & - & - & - & + & Bacillus sp. \\
\hline
\end{tabular}

Aktug (1988) studied the microbiological quality of ground cinnamon with emphasis on occurrence of Bacillus cereus in Turkey. Microbial content of eight Nigerian spices was determined by Ofuya and Uduma (1988) who found Bacillus cereus only in $15 \%$ of the samples tested. Seenappa and Kempton (1981) found Bacillus sp. as predominant microflora in dry, unprocessed Indian spices in a study conducted in Canada. Bacillus sp. was also present in the present spice samples. Therefore, it can be assumed that Staphylococcus aureus, S. epidermidis, Bacillus sp. are the most common bacteria that contaminated the spices and nuts all over the world especially in tropical countries. The presence of Bacillus, Enterobacter and Staphylococcus sp. like pathogenic bacteria made the dried foods health hazard. Staphylococcus sp. is one of the most common bacteria that could cause food poisoning. It is a pathogenic bacterium which can produce enterotoxin in foods. Bacillus cereus is also associated with food poisoning. It is able to produce endospores which persist in foods for long time and cause foodborne illness. All of these bacteria could cause serious health problems to the consumers when consumed with contaminated spices or nuts. Therefore, microbiological control is very important in food industry to prevent food poisoning and other foodborne illness during handling and processing of these spices and nuts. 


\section{References}

Aguilera MO, Stagnitta PV, Micalizzi B and De Guzman AMS 2005. Prevalence and characterization of Clostridium perfringens from spices in Argentina. Anaerobe. 11: 327-334.

Ahmed MMM, Hafez EE, Hassan MM, Hagar A, Abdelrrassoul and Mabrouk M 2014. Detection of baby milk powder contamination by microorganisms. World Applied Sciences Journal. 30(1): 93-98.

Alhussaini MS 2012. Mycobiota and mycotoxins of nuts and some dried fruits from Saudi Arabia. Journal of American Science. 8(12).

Al-Jassir MS 1992. Chemical composition and microflora of black cumin (Nigella sativa L.) seeds growing in Saudi Arabia. Food Chemistry 45: 239-242. Cited in Food Science and Technology Abstracts, 25, 2T31 (1993).

Antai SP 1988. Study of the Bacillus flora of Nigerian spices. International Journal of Food Microbiology 6: 259-261.

Banerjee M and Sarkar PK 2003. Microbiological quality of some retail spices in India Food Res. Int. 36: 469-474.

Bhar R, Geeta H and Kulkarni PR 1987. Microbial profile of cumin seeds and chilli powder sold in retail shops in the city of Bombay. Journal of Food Protection. 50: 418-419.

Burt S 2004. Essential oils: their antibacterial properties and potential applications in foods - A review. Int. J. Food Microbiol. 94: 223-253.

CDC (Centers for Disease Control and Prevention) 2009. Multistate outbreak of Salmonella infections associated with peanut butter and peanut butter containing products, the United States, 2008-2009. Morbidity and Mortality Weekly Report, 1-6 January 29/58 (Early Release).

Christensen CM, Fanse HA, Nelson GH, Bates F and Mirocha CJ 1967. Microflora of black and red pepper. Applied Microbiology 15: 622-626.

Das Francisco 2002. Bacterial and yeast counts in Brazilian commodities and spices. Brazilian Journal of Microbiology 33: 145-148.

Eklund C and Lankford CE 1967. Laboratory manual for general microbiology. Prentice-Hall International Inc. London. pp. 299.

ICMSF 2005. Spices, herbs and vegetable seasonings. In: ICMSF (International Commission on Microbiological Specifications for Foods) (Ed.), Microorganisms in Foods, Microbial Ecology of Food Commodities. Kluwer Academic/Plenum Publishers, London. pp. 360-372.

Karapinar M and Aktug SE 1986. Microbiological quality of ground cinnamon: Incidence of Bacillus cereus. Mitteilun genausdem Gebiete der Lebensmitteluntersuchung and Hygiene. 77: 520-527. Cited in Food Science and Technology Abstracts 20: 7T49 (1988).

Khan MR, Saha ML and Khan FI 2012. Bacteria associated with common spices and their possible implications. International Journal of Microbiological Research 3(1): 53-58.

Koch J, Schrauder A, Alpers K, Weber D, Frank C, Prager R, Rabsch W, Broll S, Feil F, Roggentine P, Bockemuhl J, Tschape H, Ammon A and Stark K 2005. Salmonella Agona outbreak from contaminated aniseed, Germany. Emerg. Infect. Dis. 11: 1126-1127.

Moreira PL, Lourenção TB, Pinto J, PandRall VL 2009. Microbiological quality of spices marketed in the city of Botucatu, São Paulo, Brazil. J. Food Protect. 72(2): 421-424.

Nabavi SF, Lorenzo AD, Izadi M, Sobarzo-Sanchez E, Daglia M and Nabavi SM 2015. Antibacterial effects of cinnamon: from farm to food, cosmetic and pharmaceutical industries. Nutrients 7(9): 7729-7748.

Ofuya CO and Uduma U 1986. The microbial content of some Nigerian spices. Ecology of Food and Nutrition. 19: 141-146. Cited in Food Science and Technology Abstracts, 20: 4T30 (1988).

Pafumi J 1986. Assessment of the microbiological quality of spices and herbs. Journal of Food Protection 49 : 958-963.

Salmeron J, Jordano R, Ros G and Pozo-Lora R 1987. Microbiological quality of pepper (Piper nigrum) II. Food poisoning bacteria. Microbiologie-Aliments-Nutrition 5:83-86. Cited in Food Science and Technology Abstracts 21 6T33 (1989). 
Satchell FB, Bruce VR, Allen G, Andrews WH and Gerber HR 1989. Microbiological survey of selected imported spices and associated fecal pellet specimens. Journal of the Association of Official Analytical Chemists 72: 632-637.

Seenappa M and Kempton AG 1981. A note on the occurrence of Bacillus cereus and other spices of Bacillus in Indian spices of export quality. Journal of Applied Bacteriology 50: 225-228.

Sharma A, Ghanekar AS, Padwal-Desai SR and Nadkarni GB 1984. Microbiological status and antifungal properties of irradiated spices. Journal of Agricultural and Food Chemistry 32: 1061-1063.

Sneath PHA, Mair NS, Sharpe ME, Holt JG, Frank C, Prager R, Rabsch W, Broll S and Feil F 1986. Bergey's Manual of Systematic Bacteriology $\left(9^{\text {th }}\right.$ ed.), vol. 2. Williams and Wilkins. Baltimore, London. pp. 1599.

Stankovic N, Comic L and Kocic B 2006. Microbiological correctness of spices on sale in health food stores and supermarkets in NIS. Acta Fac. Medicae NAISS 23 (2):79-84.

Witkowska A, Hickey D, Alonso-Gomez M and Wilkinson M 2011. The microbiological quality of commercial herb and spice preparations used in the formulation of a chicken supreme ready meal and microbial survival following a simulated industrial heating process. Food Control 22: 616-625.

(Manuscript received on 29 May, 2018: revised on 27 February, 2019) 